\title{
Conclusion and Further Thoughts
}

This book has shown how a specific conception of research policy, based on the conviction that scientific research has economic benefit for Europe, formed the cornerstone of the European Community's and later the European Union's activity in the field. This view was of fundamental importance for the establishment of institutions and political initiatives in an area where the EC/EU initially lacked policy competence. Linked to the continuous political desire for growth, the increasingly pervasive imperative of competitiveness, as well as to popular language about Europe's scientific and technological retard vis-à-vis its main commercial competitors, it provided research of political and ideational justification as a distinct EC/EU-level policy domain.

As much as change, this book tells a story of continuity, longevity, and durability. It illustrates the power of past in the present. We have seen how the growth-centric conception of research policy was first developed beyond the Community structures and effectively distributed and consolidated by actors working within the realm of the OECD and some national institutions. Soon, the newly formed European Commission, which closely followed the work of the OECD and was keen to expand the Community's competences into new areas, adopted this utilitarian idea of research and made it to its own. The moment for a new Community policy serving growth seemed propitious: committed to securing the expansion of national economies in the aftermath of World War II and in the context of the Cold War competition, and concerned about an allegedly increasing

(C) The Author(s) 2020

V. Mitzner, European Union Research Policy, Europe in Transition:

The NYU European Studies Series, https://doi.org/10.1007/978-3-030-41395-8_10 
separation of Europe from the technologically more advanced United States, the European political and economic elites appeared open to arguments for unifying European resources in science and innovation. With the postwar market liberalization, rapid technological change, and the gradual shift of production to the newly industrialized countries, the case for joint European research effort seemed plausible.

Maria Nedeva and Linda Wedlin have divided the development of European Union research policy in two main phases: "Science in Europe" and "European Science." According to these two scholars, the first phase, "Science in Europe," which roughly covers the time period analyzed in this book, was characterized by the principle of subsidiarity-an idea that European-level action would only be appropriate if action at a national level was insufficient; focus on increasing collaboration amongst researchers from different European countries; and concerns of the technology gap, which Nedeva and Wedlin call the "European paradox," as Europe as a world leader of science seemed to lag behind in the industrial and economic exploitation of scientific ideas. Furthermore, "Science in Europe" witnessed three distinct waves: the establishment of large, transnational facilities, such as European Organization for Nuclear Research (CERN), Euratom, European Molecular Biology Organization (EMBO), and European Molecular Biology Laboratory (EMBL); the creation of "diffuse" organizations, such as European Cooperation in Science and Technology (COST) and the European Science Foundation (ESF), including all fields of research and providing platforms for cross-national cooperation rather than supporting science at European level; and finally the creation of the EC/EU Framework Program for research, bringing the scattered research programs under one administrative umbrella. For Nedeva and Wedlin, "Science in Europe" was a period "during which a partial and fragmented science and research system was developed." It complemented rather than challenged national science, research, and innovation arrangement; it had a limited impact on universities, research institutes, and national funding agencies and landscapes; and it "didn't in a rule, include explicitly European-level research performing organizations."

This book doesn't challenge Nedeva's and Wedlin's analysis. For a long time, the EC/EU research policy had a partial character-the first initiatives were not designed to directly challenge activity in national settings. The proponents of European level activities in the field, while often ambitious and visionary, were aware of the political realities. Even the "European paradox" argument is solid, although the debate had its ebbs and flows 
and occurred in different variations depending on the context and advocates. Fears of European technological retard did push initiatives forward, at different degrees of success, giving them rationale and a sense of urgency. Also, European level research facilities were still few and far in between, and decisions in Brussels barely influenced the daily operations of universities and research institutes in the EC member states.

However, with a closer historical analysis, we also see an emerging policy that was constantly challenged, contested, and vetted by a number of groups, and in particular those who would mostly have been affected by it. And this is the vital "more to the story" that Nedeva's and Wedlin's and others' accounts do not fully tell. This book also unveils the bigger ambitions of policy-makers and dreamers by fletching out the protracted struggles for initiatives that either never quite made it to the fruition or were realized as truncated versions, to the disappointment of many. It sheds light to the already forgotten and fluid policy spaces where the feasible and unfeasible were defined, and where future pathways were sometimes painfully determined. Crucially, these spaces were shaped by broader political, social, and economic circumstances within and beyond Europe, and the prevalence and strength of specific ideational shifts and conditions, such as the fading of the naive enthusiasm about science that had characterized the immediate postwar period; increasing uneasiness about growth policies and calls for better accountability of economic and scientific activity; new limitations imposed by economic austerity; persisting distrust in European level bureaucracy among academics and national policy-makers; and ongoing political battles in other policy areas within the EC context. Yet one distinct thread runs through all these events and debates: a basic agreement on the beneficial role of research and research policy in achieving greater growth and competitiveness, and the need to create joint political mechanisms to that end. How this would eventually be achieved remained open for contestation.

Besides being a story of continuity and struggle, this book also is an account of the vulnerability of a political idea that survived, grew big, and eventually transformed European research. It was just as strong as its proponents, which at the beginning were not many. Although the Commission made sure that science policy experts would be involved in the elaboration of the various schemes from the start, these experts often represented governments and national science funding bodies rather than the broader science community. The lack of active participation of scientists and their advocates, as well as of industry and the wider public in the early 
discussion on the topic, is striking; until the 1980s, most proposals were developed in technocratic milieus with little public attention. The backing of pro-European associations such as Union des industries de la Communauté européenne (UNICE), the European Parliament, and some individuals from national research institutions and administrations remained too weak and fragmented to put significant pressure on key decision-makers.

This is the tragedy of the early EC/EU research policy. Politicians in the EC member states, whose main concern was often winning the support of the electorate, tended to focus on issues with more immediate political benefit. It was not the case that the citizens in the Community member countries had opposed the idea of the Europeanization of scientific and technological activities: in the Community's surveys of public opinion, research has consistently been at the top of the list of policies that people think should not be managed exclusively at a national level. ${ }^{2}$ Research was, nevertheless, not the kind of "high politics" that would be surrounded by glamour and drama and that would have reached the headlines. It remained distant to the lives of ordinary citizens who barely knew of the Commissions initiatives. ${ }^{3}$ It is also exactly this technical, abstract, complex, and distant nature of this policy domain that at least in part explains the persisting gap between rhetoric and reality in European research policy from the mid-1960s to the mid-1980s. For national politicians, expressing catchy phrases and stirring rhetoric about science and its many promises for the future, could be politically advantageous but also relatively safe: sacrifices in this sector rarely had a direct impact on the lives of voters, and therefore, they seldom provoked significant public protests. The late 1960s' protests at the Ispra Euratom Joint Research Centre stand out as a notable exception, as multiple employees were threatened to lose their jobs as a result of decisions made in Brussels. But in most cases, lip service in research policy came at a low political price.

In the absence of a systematic backing of scientists or their representatives, the Commission alone was too weak to induce the national governments to truly commit to developing a Community research policy. Moreover, Commission's strategy was not always consistent: important tensions prevailed between the DGs, while each Commissioner in charge of research pursued a slightly different policy. The existence of DG Research, under various names since 1967, however, became a central structure for guaranteeing institutional and ideational continuity. The DG constituted a center where bureaucrats and experts, sharing some 
important ideas and interests, could further elaborate schemes for new Community activity. This finding supports Katia Seidel's research on DGs IV (agriculture) and VI (competition), which shows that the administrative cultures developed in those DGs and the subsequent socialization of officials into these cultures, "helped to bring about policies in relevant areas, and then to keep them on track."4

Through the discussions initiated by DG Research and others, the EC gradually formed an arena for "Europeanization" 5 in research where socialization of different experts and political actors could take place. Intra-European connections were reinforced, and similarities increased, while "Europe" was given new contents and contours. At the same time, it would be misleading to argue that all contacts within the realm of the research policy debate would automatically have led to greater cohesion. These exchanges also exposed to governments and experts the diverse character of European research systems and made them aware of the difficulty in creating a strongly integrated common policy. Yet they prepared the ground for subsequent initiatives that would take off with a more favorable political momentum.

In the early 1980s, the various plans and scattered activities of the previous twenty years finally evolved into something that could be said to have an important scope and political and economic significance. The first step into this new direction was the launch of sizeable technological programs, the pioneer being European Strategic Program on Research in Information Technology (ESPRIT), an initiative that was intended to develop a European strategic scheme based on collaboration between major European companies, small- and medium-sized firms, universities, and research institutes. The project was successful: of the proposals received in response to the first call, less than 25 percent could be funded. Not surprisingly, after 1985, ESPRIT became the model for successive Community programs, such as Research in Advanced Communications in Europe (RACE) and Basic Research in Industrial Technologies (BRITE). ${ }^{6}$ The expansion of these activities led to the creation of the first framework program for research (1984-1987) in 1984. The €3.75 billion budget of the framework program, together with the budget for ESPRIT of $€ 750$ million, signified a threefold increase in the Community's research spending in 1982. Moreover, the program sparked off a steady and fast increase of the Community's research budgets. Peter Tindemans has observed that after ESPRIT, there were a growing number of scientists and industrialists involved in the consultations, projects, and evaluations, and thereby 
directly benefiting from the Community's activity in the field. This created "an almost unstoppable dynamic of pressure [that] arose in national capitals and in the Directorates-General responsible for the FP's [framework programs] to increase the budget."7

Although the role of the EC as a focal point of common European research activities remained contested, as was demonstrated by the creation of Eureka, an intergovernmental initiative intended to promote "near-market research," in 1985, and by the difficult negotiations of the subsequent framework programs, the political context had changed. National governments were now more willing to see the EC take a central role in the field, and a horizontal and vertical growth of Brussels-led activities ensued. All this was supported by the favorable conjuncture in European integration that ensued the single market program. The first framework programs were still focused on advancing applied, marketoriented research, but during the 1990s, these programs became more comprehensive and versatile as they included new mechanisms and stretched into different disciplines and sectors. They also opened up for countries outside the EC/EU framework, developed collaboration with other European and international organizations, and finally became more closely integrated with the EC/EU core policies. ${ }^{8}$ An EU-centric European research space started to emerge.

This is, indeed, where Wedlin and Nedeva see the shift to "European Science," marked by a changing understanding of the "European added value." Whereas the previous EC/EU activities had been primarily focused on fostering collaboration between researchers, now there was a widely shared desire to increase the level of integration in different aspects of European science and research. New tools were designed to strengthen the European knowledge base and to support basic research through competitive funding. ${ }^{9}$

A key concept here is the European Research Area (ERA).${ }^{10}$ Originally dreamed up by Commissioner Ralf Dahrendorf in the 1970s, the idea was revived by Commissioner Alberto Ruberti in the 1990s, and finally pushed to the center of the European political agenda by Commissioner Philippe Busquin. Endorsed as an ambitious effort to pool European scientific and technological resources, the initiative marked a clear break with the distributive approach that had characterized the EU activities in the preceding years. ${ }^{11}$ While the definition of what the ERA stands for has evolved over the years, it has brought new inclusiveness into the EU research policy and signaled a move toward a more Europeanized research policy field, 
"where the ERA agenda provides justification for the adoption of new institutions and funding tools." 12 ERA aimed to increase the Commission's autonomy in initiating projects and programs with direct implications for national activities. ${ }^{13}$ In 2012, the Commission defined ERA as "a unified research area open to the world based on the Internal Market, in which researchers, scientific knowledge and technology circulate freely and through which the Union and its Member States strengthen their scientific and technological bases, their competitiveness and their capacity to collectively address grand challenges." 14

ERA was launched in the political framework of the Lisbon European Council of March 2000, where the EU set itself the new strategic goal of becoming "the most competitive and dynamic knowledge-based economy in the world capable of sustainable economic growth, with more and better jobs and greater social cohesion." 15 In Lisbon, research and development were drawn to the center of the EU's strategy for achieving its goal by 2010 . Essentially, scientific research, technological development, and innovation were defined as key factors in growth, competitiveness, and employment in a knowledge-based European economy. ${ }^{16}$ This trend was continued in the EU's new growth strategy, Europe 2020, launched in 2010. One of the seven flagship initiatives announced in the strategy was Innovation Union, aiming to "improve conditions and access to finance and innovation, to ensure that innovative ideas can be turned into products and services that create growth and jobs." ${ }^{17}$ ERA was considered a core element of the Innovation Union and the Europe 2020 strategy. ${ }^{18}$ The EU's 2002 Barcelona target to achieve R\&D funding of 3 percent of GDP - an objective largely motivated by the higher R\&D investment levels in the United States and Japan— gave ERA additional political support and visibility. ${ }^{19}$

According to Wedlin and Nedeva, "European Science" has created "an organizational space for the support of research that is aligned, and in competition with national-level research spaces." ${ }^{20}$ A key invention in this space was the European Research Council (ERC), created in 2007 as a part of the seventh framework program. By allowing European researchers to compete with all other researchers in the EU area on the basis of excellence, ERC revolutionized the EU's approach to supporting scientific activity. With scientific excellence as the sole criterion for selection and sizeable pots of money to distribute (the first budget in the seventh framework program (2007-2013) was 7.51 billion euros, and it almost doubled for Horizon 2020, constituting 17 percent of the overall program 
budget), ${ }^{21}$ ERC soon became a powerful tool for boosting European knowledge space and shaping science in Europe.

The shifting agendas and the broadening scope of the EC/EU activities have been paralleled by the gradual strengthening of the Community's legal status. After the still very restricted formulation of the Single European Act (1986), the Treaty of Maastricht (1992) included a new Article 130, which required that "the Community and the member states shall coordinate their research and technological development activities so as to ensure that national policies and Community policy are mutually consistent." Moreover, the Commission was granted the explicit right to take any "useful initiative" to promote such consistency. ${ }^{22}$ The Amsterdam Treaty (1997) then abandoned the requirement for Council unanimity for adoption of the co-decision on the framework program. From now on, the program could be adopted by a qualified majority vote. The Union's competences in the domain were further widened by the Article 179 of Lisbon Treaty (2007), stating that:

1. The Union shall have the objective of strengthening its scientific and technological bases by achieving a European research area in which researchers, scientific knowledge and technology circulate freely, and encouraging it to become more competitive, including in its industry, while promoting all the research activities deemed necessary by virtue of other Chapters of the Treaties.

2. For this purpose the Union shall, throughout the Union, encourage undertakings, including small and medium-sized undertakings, research centres and universities in their research and technological development activities of high quality; it shall support their efforts to cooperate with one another, aiming, notably, at permitting researchers to cooperate freely across borders and at enabling undertakings to exploit the internal market potential to the full, in particular through the opening-up of national public contracts, the definition of common standards and the removal of legal and fiscal obstacles to that cooperation.

3. All Union activities under the Treaties in the area of research and technological development, including demonstration projects, shall be decided on and implemented in accordance with the provisions of this Title. ${ }^{23}$ 
Within ten years, the EC/EU research policy activity had firmly become woven into the legal fabric of the Union.

While the EC's/EU's legal base strengthened and its activities broadened, the Community/Union gradually moved into territories traditionally occupied not only by European nation-states but also by various intergovernmental organizations promoting research. In this book we have seen how already in the 1960s and 1970s, the EC challenged more established organizations such as the OECD and the Council of Europe. In the subsequent years, this trend continued. Indeed, as the EU is thus increasingly dominating the European research field, one can observe an incremental transformation of previously non-EC/EU projects and institutions into EU or quasi-EU projects and institutions, or alternatively, a launching of new EU operations practically identical to existing activities in other European organizations. A good example here is space research. The cooperation agreement signed between the EU and the European Space Agency in 2003 constituted a new framework for a comprehensive European space policy involving the coordination of the actions of the European Commission and ESA through a Joint Secretariat, a small team of EU administrators and ESA executives, as well as ministerial-level meetings in the Space Council. In 2007 there was a further development when twenty-nine European countries expressed their support for a European space policy, prepared jointly by the European Commission and the ESA's director-general. Moreover, the Lisbon Treaty gave the European Union an explicit competence in space, calling for the development of a European space program. The implementation of this program has further increased cooperation between the EU and the ESA. In the recent past, almost 20 percent of the funds managed by ESA have originated from the EU budget. $^{24}$

The European Science Foundation, on the other hand, after almost nearing death in 2011, ${ }^{25}$ has acknowledged the EU's growing role in promoting European science and wound down all its collaborative research instruments and networks. With a stated mission to serve the European Research Area for the sole benefit of science, it now focuses on running an expert division called Science Connect that provides services to the science community. This is a significant shift: since its creation in 1974, ESF has run over 2000 world-class science programs and networks, with support from eighty member organizations in thirty countries. ${ }^{26}$ Through this work, it has made a solid contribution to the creation of the European research space. In the most recent years, its financial resources, however, 
have faced a dramatic downturn. Between 2010 and 2015, the ESF member contributions diminished by 15.4 million euros. These budget cuts, together with the wishes of its members, led ESF to radically reduce its activities and staff and to move policy-related work into newly formed Science Europe. ${ }^{27}$ COST, another intergovernmental institution supporting European research set up in the early 1970s and analyzed in this book, has weathered the emergence of a comprehensive EU research policy somewhat better. It fills a specific niche in the European research funding landscape as an organization providing financial support for the creation of European-wide multi-stakeholder research networks, called COST Actions. Most of COST's funding, however, comes from the EU research framework program, ${ }^{28}$ which makes it highly dependent on the political developments in the Union.

The various impacts of the emergent EU research policy on the wider European research space still deserve more thorough scholarly attention. ${ }^{29}$ One interesting trend, however, is the emergence of stronger and more organized organizations and networks promoting the interests of researchers, research funders, and the higher education sector at the European level. These include EuroScience, a grassroots non-profit organization of researchers in Europe, created in 1997 to shape policies for science, technology, and innovation. With its 2600 individual members, EuroScience aims to be "a direct and democratic way to influence the construction of the Europe of Science and Technology, for the benefit of Europe's international position in science, and to enhance science's contribution to society, opportunities and mobility for both young and experienced researchers." 30 The European Association of Research and Technology Organizations (EARTO) was established two years later to promote research and technology organizations and represent their interest in Europe. Its current activities are geared toward influencing the EU policy. ${ }^{31}$ In 2001, a merger between the Association of European Universities and the Confederation of European Union Rectors' Conferences led to the creation of the European University Association (EUA). EUA represents over 800 universities in forty-eight countries, and its activities are targeted at influencing the EU policies on higher education, research, and innovation. $^{32} \mathrm{~A}$ year later, another Belgium-based organization, the League of European Research Universities (LERU), was formed with the objective to "advance the understanding and knowledge of decision makers, policy makers and opinion leaders about the role and activities of research-intensive universities." ${ }^{33}$ Both institutions seek to promote the 
interests of higher education and research institutions in EU policymaking. In 2011, twenty-three countries joined in the founding assembly of Science Europe, an organization representing research funders and other research organizations in the EU. Science Europe was built from two former advocacy groups, the ESF and EuroHORCS (an organization of the heads of the European research councils), aspiring to give its members a stronger and more united voice on European level policy. ${ }^{34}$ The list could be continued, in particular if one includes more informal networks and alliances.

The rise of these various groups is largely a response to the gradual strengthening of the EU's research arm, which has made advocating for researchers' and research and higher education institutions' interests in Brussels a worthwhile endeavor. Undoubtedly, there is a new reality for research in Europe. The current EU research funding program is exceptional in its size, long duration (seven years), budgetary framework stability, and scope: it encompasses research as well as innovation; grants as well as loans, equity, and procurement; it combines a broad top-down focus on grand societal challenges with bottom-up "frontier" research; it is crossborder and cross-sectoral, encouraging inter-disciplinary collaboration, mobility, and coordination. And it is attracting increasing attention and interest within research communities both within and beyond Europe. The Horizon 2020 mid-term evaluation accounted a 65 percent increase in the annual number of applications compared to the program's predecessor, the seventh framework programme (FP7). With an 11.6 percent success rate, which was much lower than under FP7 (18.4 percent), the competition for Horizon 2020 grants had become fierce. While 92.8 percent of funding went to participants from the $28 \mathrm{EU}$ member states, the program involved people from over 130 countries. ${ }^{35}$ Moreover, EU-funded projects are also producing top-notch research. Between 2014 and 2016 alone, Horizon 2020, supporting approximately 340,000 researchers, produced more than 4000 peer-reviewed publications that were cited more than twice the world average. Two-thirds of them were also openly accessible to the public. ${ }^{36}$ It is also noteworthy that within the European institutions, research has taken a prominent role. In 2016, a total of 1000 of the Commission's 23,000 officials worked for DG Research, making this DG the fourth largest division. If this number were to include staff members in the EU Joint Research Centre, research would occupy the first place. Research also continues to be the third largest item in the EU budget. ${ }^{37}$ 
Despite the prevailing uncertainties about the future of European integration and the different priorities of the member states, the trend of strengthening the role of the EU in supporting and shaping European research is likely to continue. In June 2018 , the Commission published its proposal for the next EU funding program, Horizon Europe, which would cover the years of 2021-2027, involve a budget of 100 billion euros-an increase from Horizon 2020 - and be "the most ambitious research and innovation funding programme ever." 38 There was little modesty in the Commission's statement that "'[b] eneficiaries' research capacities and scientific outputs would have significantly decreased had they received national funding instead. This decrease would have been especially large in terms of their ability to collaborate with industry and business, transfer of knowledge, the number of participations in scientific conferences and the knowledge in new areas." ${ }^{39}$ The Covid-19 outbreak in 2020, effectively highlighting the importance of research in tackling global crisis is likely to give a further boost to EU research and innovation activities. The EU acted relatively fast by providing emergency funding from Horizon 2020 and processing proposals at a record speed.

One could note emerging tensions between European and national research spaces, as the national funding bodies and the EU instruments might increasingly compete for resources, applicants, and legitimacy. ${ }^{40}$ The larger the EU research budget grows, and the more extensive the European level programs become, the more accentuated this competition will become. Already now the EU research funding programs include almost all research themes and forms of research promotion that exist in national research and technology policies. ${ }^{41}$

Linda Wedlin and Maria Nedeva explain the shift from "Science in Europe" to "European Science" by two important changes in policy rationales and framing. First, the understanding of "European added value" shifted from focusing on coordination to incorporating competition. Epitomized in the creation of the European Research Area, which signaled a move away from collaboration toward integration, this new framing precipitated the implementation of policy instruments that stretched beyond simple support for collaboration between researchers and encouraged genuine competition between them. Second, there was growing evidence and concern that Europe was not doing so well in science compared with its main commercial competitors. This new version of the technology gap debate argued for a European retard that was more fundamental than failure in making the link between scientific research and commercial 
applications. "By 2000," Wedlin and Nedeva write, "the long-standing assumption of this 'European paradox' morphed into a full-blown 'gap' argument, that is, that Europe was clearly lagging behind the USA and Japan both in terms of science and its application." 42 This concern led to a change of rationales and the target for policy intervention. It served as a justification for a powerful move to the realm of basic science and the creation of the European Research Council.

Tim Flink, through an analysis on the creation of ERC, supports this finding. A renewed concern of European global retard and a conviction of the need to strengthen the European knowledge base underpinned a political discussion that ushered the birth of ERC. Moreover, language played a critical role: with the concept "frontier research," the European Commission avoided directly violating the principle of subsidiarity, which had curtailed its activity in basic research — an area traditionally belonging to the nation states. "Frontier research," falling somewhere in between basic and applied research, aligned well with the EU's traditional mission of fostering European competitiveness and the geopolitical objective of the Lisbon Strategy to make Europe the world's leading commercial power, drawing its strength from knowledge. "Frontier research" projected an image of global competition, and it made a solid reference to Vannevar Bush's monumental report Science, the Endless Frontier ${ }^{43}$ and the founding myth of the US National Science Foundation. "[I]n this policy process," concludes Flink, "the narrative structure only seemed to be successful if it followed the chimera of a geostrategic security understanding (isolation by the European Research Area) and a prosperity identity (market imperative of the EU)." 44

Also, Terttu Luukkonen, while noting the critical role of stakeholder groups, such as the leading life sciences organizations, stresses the role of the gap debate in the formation of the ERC. "There was a concern," she writes, "about funding being too low for basic research and about quality of science and its institutions in Europe and, as in European research policy in general, USA provided a benchmark with which comparisons were made." Furthermore, the focus on frontier research, provided "a strong argument that the ERC is justified from the point of view of technological and economic competitiveness, not just of scientific competitiveness." 45 This is confirmed by just a cursory reading of the Commission's documents from that time period. The prominence of economic concerns and the gap narrative is striking, as well as the discourse that highlights the insufficiency of national initiatives. The Commission's proposal for ERA, 
for example, argues that in Europe, "the situation concerning research is worrying. Without concerted action to rectify this the current trend could lead to a loss of growth and competitiveness in an increasingly global economy. The leeway to be made up on the other technological powers in the world will grow still further. And Europe might not successfully achieve the transition to a knowledge-based economy." 46

The discursive continuity is remarkable. Throughout this book we have seen how European Commission officials and other supporters of greater EU competences in the field of research used a specific language and political framing to advance their initiatives. This language presented scientific research as an engine for economic growth and material prosperity, which were widely accepted as favorable political goals by the European governing elites. Combined with arguments about European technological delay vis-à-vis its main commercial competitors, it presented an increasingly convincing case for new European level activity. By the early 1980s, these framings had become dominant truth claims in the European debates, and they started to essentially determine political agendas. At the same time, the scope and nature of the scientific enterprise changed, the pace of discovery and innovation accelerated, and as a result, not only did competition between research institutes, nations, and individual researchers accentuate, but science and technology became increasingly vital forces shaping societies and determining the geopolitical and economic success of countries.

It could be argued that one reason for the continuous popularity of the instrumental-economic conception of research policy has been its malleability and extraordinary ability to adapt to different political conditions. As amenable as it seemed to the Western European expansive welfare economies of the 1960s and 1970s, it has proved perfectly compatible with the intensifying drive for market liberalism since the early 1980s. This is not only because of the prevailing appeal of growth. Research policy has proved useful in facilitating and accelerating the shift to the world of open markets. In this study we have seen how research policy, especially at European level, was commonly pictured as a means to adapt to an exogenous and irreversible transformation that later became labeled as globalization.

The EU research policy came into being with an explicit objective of enhancing European economic performance in an international framework in which competition was accelerating. This goal remains as one of the guiding principles of the current EU research policy. When Research 
Commissioner Máire Geoghegan-Quinn in November 2011 said: "fundamentally, support through Horizon 2020 for research, innovation and science is an economic policy," 47 she reiterated the principle on which the Union's activity had been based since the very beginning. The economic framing remains sturdily in place. The Horizon 2020 mid-term evaluation report, for example, made a blatant calculation a GDP gain, concluding that "[e]very euro invested under Horizon 2020 brings back 6 to 8.5 euros." 48 The explanatory memorandum included in the Commission's proposal for establishing Horizon Europe included similar calculations. According to the memorandum, Horizon Europe was expected to generate positive effects on growth, with an increase of GDP on average by 0.08 percent to 0.19 percent over twenty-five years, "which means that each euro invested can potentially generate a return of up to 11 euro of GDP over the same period"-better ratio than in Horizon 2020. The memorandum went on to calculate that discontinuing the Union research and innovation program could result in a decline of competitiveness and growth up to 720 billion euros of GDP loss over twenty-five years. ${ }^{49}$

To some degree, the EU is tied to this language. Initially, the lack of a solid juridical basis for research policy forced the Commission to frame research as a tool for achieving prosperity, which has traditionally been one of the Union's core objectives. Although the gradual strengthening of the juridical basis of research policy during the last three decades has granted the Commission more room for maneuver, the EU's activity and ambitions are still limited by the principle of subsidiarity and the constant search for European added value. The EU is most likely to gain legitimacy by anchoring its initiatives and programs to the objectives of competitiveness and growth-a territory where EU activity is seldom questioned. But continuously liking research and growth and articulating science and innovation policy in economic terms, is more than a smart political strategy. It is a durable policy framing that was constructed in the early $1960 \mathrm{~s}$ and that has been broadly embraced and absorbed by national decisionmakers, European officials, and a number of other actors shaping research policy. It embodies a very specific understanding of the role of science and research in society and the objectives of public support for research and innovation communities.

Policy framings can and need to change if they become unsuited to responding to the society's most pressing needs and challenges. Johan Schot and W. Edward Steinmueller, for example, have argued for a new framing for innovation policy, "linked to contemporary social and 
environmental challenges such as the Sustainable Development Goals and calling for transformative change." This framing should take priority over the two existing framings, which emerged in the 1960s and 1980s, and which, while still relevant, "offer little guidance for managing the substantial negative consequences of the socio-technical system of modern economic growth to which they have contributed and of which they are a part." ${ }^{50}$ The first framing, which dominated during the time period analyzed in this book and-as we have seen-still influences EU policy, emphasized the role of research and innovation for increasing economic growth, aimed at boosting the potential for science and technology for prosperity, and cultivated socio-technical systems supporting mass production and consumption. The second framing gained ground toward the late 1980s and more explicitly aimed to address challenges related to intensifying international competition and globalization. With a focus on developing and analyzing national systems of innovation, enhancing capacities for learning, and supporting connectivity between different societal sectors within the system, it added a layer of sophistication and complexity to the first framing. However, it didn't depart from the premises of increasing growth through maintained and improved competitiveness. ${ }^{51}$

The third framing suggested by Schot and Steinmueller draws upon the recognition that a deep and rapid transformation of socio-technical systems is needed in the backbone systems of modern societies, including energy, mobility, food, water, healthcare, and communication, and that research and innovation policy has a vital role to play in supporting this transformation. That requires a dramatic change in thinking, broadening of perspectives and alliances, and setting entirely new goals and objectives. According to the two authors, this new framing "focuses on innovation as a search process on the system level, guided by social and environmental objectives, informed by experience and the learning that accompanies that experience, and a willingness to revisit existing arrangements to deroutinize them in order to address societal challenges." Further, the innovation process in this framing "is likely to be effective in achieving these goals if it is inclusive, experimental and aimed at changing the direction of socio-technical systems in all its dimensions." ${ }^{52}$ Essentially, this framing will propose building a new knowledge base, setting up mission-oriented policies with missions formulated in an open-ended way, encouraging new forms of engagement and networks between public, private, and third sector actors, and supporting intermediary actors to advocate competitive 
niches, as well as new visions and policies. It will mean a shift away from the old research and innovation policy proposition that social and economic goals can be achieved through economic growth if surpluses are redistributed and technocratic elites can regulate the externalities of growth. A more comprehensive and ambitious - if not radical-approach is needed to ensure the continued relevance of research and innovation policy in the contemporary world in rapid transition..$^{53}$

Schot and Steinmueller are not alone with this proposition. In the last few years, there has been increasing scholarly interest in rethinking the premises of science and innovation policy and exploring ways of better aligning policy objectives with broader social and environmental challenges. ${ }^{54} \mathrm{~A}$ new policy paradigm is emerging, "layered upon but not fully replacing earlier paradigms of science and technology and innovation systems policy." According to Gijs Diercks, Henrik Laren, and Fred Steward, this "'normative turn' that is currently taking place insists that innovation policy must not only optimize the innovation system to improve economic competitiveness and growth, but also include strategic directionality and guide processes of transformative change towards desired societal objectives." Further, this "emerging paradigm of transformative innovation policy is still a heavily contested discursive space" and "there is considerable uncertainty regarding the paths of this paradigm shift in the making." 55

Looking at the most recent EU language on research and innovation policy, one can discern elements of this shift. While competitiveness and growth retain a solid place in the Framework Programs, with the increasing focus on strengthening the European knowledge base and the objective of tackling grand societal challenges through research, the political framing of the EU research policy has widened. ${ }^{56}$ One of the earliest visible expressions of this ambition was the declaration, endorsed by over 300 researchers, policy-makers, and representatives from industry and research funding institutions during the 2009 "New World - New Solutions" conference in Lund, Sweden. ${ }^{57}$ The declaration stated that "European research must focus on the Grand Challenges of our time moving beyond current rigid thematic approaches. This calls for a new deal among European institutions and Member States, in which European and national instruments are well aligned and cooperation builds on transparency and trust." The "Grand Challenges" listed in the declaration included global warming; tightening supplies of energy, water, and food; aging societies; public health; pandemics; and security. The Lund Declaration also states that the "European Knowledge Society must tackle the overarching challenge of 
turning Europe into an eco-efficient economy." ${ }^{58}$ Since then, broader social and global concerns have found a firmer footing in the EU's research policy agenda. ${ }^{59}$ Between 2014 and 2016, a total of 37 percent of Horizon 2020 funding went to reinforcing and extending the excellence of European science base and consolidating the ERA. The second biggest pot, 36 percent, went to stimulating a critical mass of research and innovation efforts to help address grand societal challenges. Promoting industrial leadership came only as third, with 22 percent of funding. The remaining 5 percent was dedicated to other priorities, such as widening participation, including society, Euratom, and the pilot for fast-tracking innovation. ${ }^{60}$

The three pillars of Horizon Europe-Excellent Science, Global Challenges and European Industrial Competitiveness, and Innovative Europe-seem to continue this trend, although the Commission notes that "[i]industrial leadership will be prominent in this [Global Challenges] pillar and throughout the program as a whole." ${ }^{161}$ Indeed, the proposal for Horizon Europe was "framed by the premise that research and innovation (R\&I) delivers on citizen's priorities, boosts the Union's productivity and competitiveness, and is crucial for sustaining our socio-economic model and values, and enabling solutions that address challenges in a more systematic way." In other words, "Horizon Europe will strengthen the Union's scientific and technological bases in order to help tackle major global challenges of our time and contribute to achieving the Sustainable Development Goals (SDGs). At the same time, the programme will boost the Union's competitiveness, including that of its industries." 62 These quotes reveal a striking feature in the Commission's blueprints for Horizon Europe: an effort to achieve the double objective of responding to global challenges and maintaining economic growth. Overall, however, the program seems to be defined as serving the European economy. In March 2019, Carlos Moedas, the Research Commissioner, noted that "ware now on track to launch the most ambitious ever European research and innovation programme in 2021, shaping the future for a strong, sustainable and competitive European economy and benefiting all regions in Europe." ${ }^{\prime 3}$ Even the Lund Declaration underlines that " $[\mathrm{m}]$ eeting the Grand Challenges will be a prerequisite for continued economic growth." ${ }^{64} \mathrm{~A}$ vital task for the Commission and the Union more broadly in the future will be resolving the tension between its traditional policy goals of pursuing growth and competitiveness and its newer mission of tackling grand challenges and promoting sustainability transitions. Can both objectives be successfully pursued in parallel, and how possible conflicts between 
growth and broader socio-environmental issues can be reconciliated, has not explicitly been addressed in any of the key documents or declarations-until very recently.

Ursula von der Leyen's Commission's proposal for a European Green New Deal contains explicit language, suggesting that the challenge of climate change can be addressed without compromising economic growth and competitiveness. It presents the European Green New Deal as "a new growth strategy that aims to transform the EU into a fair and prosperous society, with a modern, resource-efficient and competitive economy where there are no net emissions of greenhouse gases in 2050 and where economic growth is decoupled from resource use." Moreover, "careful attention will have to be paid when there are potential trade-offs between economic, environmental and social objectives." The language stressing the EU's "collective ability to transform its economy and society to put it on a more sustainable path," outlines an ambitious and transformative vision that departs from narrow sectorial propositions. In the European New Green Deal, science and innovation also has a solid place. The document calls for "new technologies, sustainable solutions and disruptive innovation" and notes that "conventional approaches will not be sufficient." The EU's new research and innovation agenda will emphasize experimentation, and working across sectors and disciplines, thereby taking the "systemic approach needed to achieve the aims of the Green Deal." ${ }^{\prime 5}$ For now it seems that four of Horizon Europe's five research missions would be closely linked to the Green Deal objectives. ${ }^{66}$ Also, how the Covid-19 pandemic transforms the European research landscape, remains to be seen.

In the last few decades, the EU has shown an important capacity of selfcriticism and learning. Horizon Europe is being built on lessons learned in Horizon 2020, such as the need for increasing support for breakthrough innovation; adopting mission-orientation and encouraging citizen involvement; strengthening international cooperation; reinforcing openness; rationalizing the funding landscape; and encouraging participation. New initiatives in Horizon Europe, such as European Innovation Council, address these objectives. ${ }^{67}$ Ursula von der Leyen's Commission has set a new level of ambition for achieving a pressing transformative change that transcends several sectors of European society. The rapid response to Covid-19 also shows proactivity and agility from an institution often seen as stiff and bureaucratic. These serve as demonstrations that the EU does not need to or even cannot be constrained by its past policy framings and 
discourses. And this is a real opportunity. In today's Europe, torn by nationalism and distrust in governing elites, preserving peace and producing prosperity no longer suffice to provide the legitimacy that carried the process of European integration this far. It is time for a more powerful and compelling mission, aiming at a profound socio-technological transformation that a Union-wide science and research effort is well positioned to shape and realize.

Despite its contested origins, research policy has become one of the EU's core instruments for advancing its policies, promoting European integration, and achieving change. It has won the support of researchers, both in Europe and beyond, gained prestige, and found a solid place on the EU political agenda. With its extensive programs and significant funding, it has transformed the European research landscape for good. However, to remain relevant, the EU research policy needs to be tailored to serve the most compelling needs of the European societies. If designed right, it can be a powerful force, enabling critical and truly transformative effort for which none of the individual member states would be capable alone.

\section{Notes}

1. Maria Nedeva and Linda Wedlin, "From 'Science in Europe' to 'European Science," in Linda Wedlin and Maria Nedeva, eds. Towards European Science. Dynamics and Policy of an Evolving European Research Space (Cheltenham and Northampton: Edvard Elgar Publishing, 2015): 12-36.

2. European Commission: Science and Public Opinion (1977), available at: http://ec.europa.eu/public_opinion/archives/ebs/ebs_9_en.pdf (accessed December 25, 2019); European Commission, Qualitative Study on the Image of Science and the Research Policy of the European Union, October 2008, available at: https://ec.europa.eu/commfrontoffice/ publicopinion/index.cfm/Survey/getSurveyDetail/yearFrom/1974/ yearTo/2019/search/research\%20policy/surveyKy/740 (accessed December 25, 2019).

3. A 2008 Commission survey found that among the European citizen, "the degree of knowledge on European research policy is extremely low." European Commission, Qualitative Study on the Image of Science and the Research Policy of the European Union, October 2008, available at: https://ec.europa.eu/commfrontoffice/publicopinion/index.cfm/ Survey/getSurveyDetail/yearFrom/1974/yearTo/2019/search/ research\%20policy/surveyKy/740 (accessed December 25, 2019). 
4. Katia Seidel, The Process of Politics in Europe. The Rise of European Elites and Supranational Institutions (London and New York: I.B Tauris Publishers, 2010): 154.

5. For a discussion on Europeanization from a historical perspective, see Martin Conway and Kiran Klaus Patel, eds. Europeanization in the Twentieth Century: Historical Approaches (New York: Palgrave, 2010).

6. John Peterson and Margaret Sharp, Technology Policy in the European Union (Basingstoke: Macmillan, 1998): 6, 70-78.

7. Peter Tindemans, "Post-war Research, Education and Innovation PolicyMaking in Europe," in European Science and Technology Policy, Towards Integration or Fragmentation? Eds. Henri Delanghe, Ugur Muldur, and Luc Doete (Cheltenham and Northampton: Edward Elgar, 2009): 13-14.

8. Veera Mitzner, "Research Policy," The European Commission 1986-2000. History and Memory of an Institution, ed. Vincent Dujardin et al. (Luxembourg: European Commission, 2019): 321-334.

9. Linda Wedlin and Maria Nedeva, eds. Towards European Science. Dynamics and Policy of an Evolving European Research Space (Cheltenham and Northampton: Edvard Elgar Publishing, 2015): 23-25.

10. European Commission: Towards a European research area, Brussels, 18.1.2000, $\operatorname{COM}(2000) 6$ final, available at: http://eurlex.europa.eu/ LexUriServ/LexUriServ.do? uri=COM:2000:0006:FIN:EN:PDF (accessed December 7, 2019). For the development of ERA, see e.g. Thomas Banchoff, "Political Dynamics of the ERA," in Changing Governance of Research and Technology Policy - The European Research Area, eds. Jakob Edler, Stefan Kuhlmann and Maria Behrens (Cheltenham, UK and Northampton, MA: Edward Elgar, 2003).

11. Luis Sanz Memémdez and Susana Borràs, "Explaining Changes and Continuity in EU Technology Policy: The Politics of Ideas," in The Dynamics of European Science and Technology Policies, eds. Simon Dresner and Nigel Gilbert (Aldershot and Burlington: Ashgate, 2001): 41.

12. Terttu Luukkonen, "European Research Area: An Evolving Policy Agenda," in Towards European Science. Dynamics and Policy of an Evolving European Research Space, eds. Linda Wedlin and Maria Nedeva (Cheltenham/Northampton: Edvard Elgar Publishing, 2015): 37.

13. Banchoff, "Political Dynamics," 81-82.

14. European Commission Communication: A Reinforced European Research Area Partnership for Excellence and Growth, Brussels, July 17, 2012, available at: https://ec.europa.eu/research/science-society/document_ library/pdf_06/era-communication-partnership-excellence-growth_en. pdf (accessed December 15, 2019).

15. Quoted in Luca Guzzetti, “The 'European Research Area' idea in the history of Community policy-making," in European Science and Technology 
Policy. Towards Integration or Fragmentation? Eds. Henri Delanghe, Ugur Muldur, and Luc Doete (Cheltenham and Northampton: Edward Elgar, 2009): 73.

16. Luukkonen, "European Research Area," 39.

17. European Commission Communication: Europe 2020 Flagship Initiative Innovation Union, Brussels October 6, 2010, available at: http://ec. europa.eu/research/innovation-union/pdf/innovation-union-communication_en.pdf\#view=fit\&pagemode=none (accessed December 25, 2019).

18. European Commission Communication: A Reinforced European Research Area Partnership for Excellence and Growth, Brussels July 17, 2012, available at: https://ec.europa.eu/research/science-society/document_ library/pdf_06/era-communication-partnership-excellence-growth_en. pdf (accessed December 25, 2019).

19. Inga Ulnicane, "Broadening Aims and Building Support in Science, Technology and Innovation Policy: The Case of the European Research Area," Journal of Contemporary European Research, l (2015): 31-49 (40).

20. Weldin and Nedeva, "Towards European Science," 25.

21. Tim Flink, Die Entstehung des Europäischen Forschungsrates: Marktimperative - Geostrategie - Frontier Research (Weiserswist: Velbrück Wissenschaft, 2016): 15.

22. Peterson and Sharp, Technology Policy, 116.

23. Consolidated version of the Treaty on the Functioning of the European Union-Part Three: Union Policies and Internal Actions, Title XIX: Research and technological development and space-Article 179 (ex Article 163 TEC), available at: https://eur-lex.europa.eu/legal-content/ EN/TXT/?uri=CELEX\%3A12016E179 (accessed December 25, 2019).

24. ESA website, https://www.esa.int/About_Us/Corporate_news/ESA_ and_the_EU (accessed December 24, 2019).

25. Martin Hynes, "The European Science Foundation; Death or Mid-Life Crisis?" Europhysics News 46/1 (2015), 23-26.

26. The Science Connect Website, http://www.esf.org/esf/frequently-askedquestions/\#content-1458 (accessed December 10, 2019).

27. Hynes, "The European Science Foundation," 24.

28. COST website: https://www.cost.eu/who-we-are/about-cost/ (accessed December 25, 2019).

29. Wedlin and Nedeva, "From 'Science in Europe," 30.

30. EuroScience website: https://www.euroscience.org/about/\#about-us (accessed December 25, 2019).

31. EARTO website: https://www.earto.eu/about-earto/ (accessed December 25. 2019).

32. EUA website: https://eua.eu/about/who-we-are.html (accessed December 25, 2019). 
33. LERU website: https://www.leru.org/mission (accessed December $25,2019)$.

34. Daniel Clery and Gretchen Vogel, "European Research Heads Get a New Body," Science, October 21, 2011; "Science Europe lobby group hit by sudden exodus. Brussels-based advocacy group aimed to provide single voice for scientists in the EU-but is losing members," Nature, November 29, 2016.

35. European Commission, Key Findings from the Horizon 2020 Interim Evaluation, (Brussels: European Union, 2017), 3-4, 8, available at: https://ec.europa.eu/research/evaluations/pdf/brochure_interim_evaluation_horizon_2020_key_findings.pdf (accessed December 25, 2019).

36. Ibid., 10.

37. Tim Flink, "EU-Forschungspolitik—von der Industrieförderung zu einer pan-europäischen Wissenschaftspolitik?" In Handbuch Wissenschaftspolitik, eds. D. Simon et al. (Springer Reference Sozialwissenschaften, 2016), 80.

38. European Commission, "Proposal for a decision of the European Parliament and of the Council on establishing the specific programme implementing Horizon Europe-the Framework Programme for Research and Innovation," COM/2018/436 final-2018/0225 (COD), available at: https://eur-lex.europa.eu/legal-content/EN/TXT/?uri=COM\% 3A2018\%3A436\%3AFIN (accessed December 25, 2019); European Commission, "EU funding for Research and Innovation 2021-2027," Factsheet, June 7, 2018, available at: https://ec.europa.eu/commission/ publications/research-and-innovation-including-horizon-europe-iterand-euratom-legal-texts-and-factsheets_en (accessed December 25, 2019).

39. European Commission, Key Findings from the Horizon 2020 Interim Evaluation, (Brussels: European Union, 2017), 18, available at: https:// ec.europa.eu/research/evaluations/pdf/brochure_interim_evaluation_ horizon_2020_key_findings.pdf (accessed December 25, 2019).

40. Wedlin and Nedeva, "From 'Science in Europe," 31.

41. Flink, "EU-Forschungspolitik," 79.

42. Wedlin and Nedeva, "From 'Science in Europe," 23-25.

43. Vannevar Bush, Science, the endless frontier. A report to the President by Vannevar Bush, director of the Office of scientific research and development. (Washington D.C., United States Government Printing Office, 1945).

44. Flink, Die Entstehung, 20-21; 327-328. The author's translation from German.

45. Luukkonen, "European Research Area," 48-49, 51.

46. European Commission: Communication from the Commission to the Council, the European Parliament, the Economic and Social Committee, and the Committee of the Regions: Towards a European Research Area. 
Brussels, January 1, $2000 \operatorname{COM}(2000) 6$ final, available at: https://eurlex.europa.eu/legal-content/EN/TXT/PDF/?uri=CELEX:52000 DC0612\&from=EN (accessed December 25, 2019).

47. Máire Geoghegan-Quinn, European Commissioner for Research, Innovation and Science: Remarks at press conference launching Horizon 2020 Press conference Brussels, November 30, 2011, Speech/11/033, available at: http://europa.eu/rapid/pressReleasesAction.do? reference $=S$ PEECH/11/833\&format=HTML\&aged=0\&language=EN\&guiLangua ge $=$ en (accessed December 25, 2019).

48. European Commission (Directorate-General for Research and Innovation), Key Findings from the Horizon2020 Interim Evaluation, (Brussels: European Union, 2017), 13, available at: https://ec.europa.eu/research/ evaluations/pdf/brochure_interim_evaluation_horizon_2020_key_findings.pdf (accessed December 25, 2019).

49. European Commission: Proposal for a regulation of the European Parliament and of the Council establishing Horizon Europe-the Framework Programme for Research and Innovation, laying down its rules for participation and dissemination, Brussels, June 7, 2018, COM(2018) 435 final, available at: https://eur-lex.europa.eu/legal-content/EN/TXT /?uri=COM\%3A2018\%3A436\%3AFIN (accessed December 25, 2019).

50. Johan Schot and W. Edward Steinmueller, "Three Frames for Innovation Policy: R\&D, Systems of Innovation and Transformative Change," Research Policy 47 (2018): 1554.

51. Ibid., 1554-1561.

52. Ibid., 1563 .

53. Ibid., 1561-1565.

54. See, e.g. Egil Kallerud, "Goal Conflicts and Goal Alignment in Science, Technology and Innovation Policy Discourse," Working Paper (Oslo: Nordic Institute for Studies in Innovation, Research and Education, 2010); K. Matthias Weber and Harald Rohracher, "Legitimizing Research, Technology and Innovation Policies for Transformative Change. Combining Insights from Innovation Systems and Multi-Level Perspective in a Comprehensive 'Failures' Framework," Research Policy, 41 (2012): 1037-1047; Stefan Kuhlmann and Andre Rip, "Next Generation Innovation Policy and Grand Challenges," Science and Public Policy, 45 (2018): 448-454; Gijs Diercks, Henrik Larsen, and Fred Steward, "Transformative Innovation Policy: Addressing Variety in an Emerging Policy Paradigm," Research Policy 48 (2019): 880-894. In addition to scholars in STS and sustainability transitions studies, there have also been historians arguing for a change. For instance, Andrew Jamison wrote in 2014 that "as in the 1960 s, there is a need for fundamentally rethinking the relations between science, technology, and society, in Europe as well as 
internationally. In particular, there needs to be much more coordination between policies for science and technology and all the other policies that national governments, as well as local authorities and intergovernmental bodies pursue. In order to meet the challenge of climate change and sustainable development, science and technology need to be reconfigured so that the 'solutions' they provide can be relevant for the problems that humanity faces. And in order to provide appropriate solutions, scientists and engineers will need to be better educated about the problems that need to be solved." Andrew Jamison, "Science and Technology in Postwar Europe," in The Oxford Handbook of Postwar European History, ed. Dan Stone (Oxford: Oxford University Press, 2014): 647-648.

55. Diercks, Larsen, and Steward, "Transformative Innovation Policy," 881,884 .

56. Luukkonen, "European Research Area," 39; Ulnicane, "Broadening Aims," 31-49.

57. European Commission, Cordis: "Swedish Presidency: Research Must Focus on Grand Challenges," July 10, 2009, available at: https://cordis. europa.eu/article/id/31013-swedish-presidency-research-must-focuson-grand-challenges (accessed December 15, 2019).

58. European Commission: The Lund Declaration: Europe Must Focus on the Grand Challenges of our Time, July 2009.

59. Luukkonen, "European Research Area," 44.

60. European Commission (Directorate-General for Research and Innovation), Key Findings from the Horizon 2020 Interim Evaluation, (Brussels: European Union, 2017), 3-4, available at: https://ec.europa.eu/ research/evaluations/pdf/brochure_interim_evaluation_horizon_2020_ key_findings.pdf (accessed December 25, 2019).

61. European Commission Factsheet, EU Budget for the Future. Research and Innovation, May 2, 2018, available at: https://ec.europa.eu/commission/sites/beta-political/files/budget-proposals-research-innovationmay2018_en.pdf (accessed December 15, 2019).

62. European Commission: Proposal for a regulation of the European Parliament and of the Council establishing Horizon Europe-the Framework Programme for Research and Innovation, laying down its rules for participation and dissemination, Brussels, June 7, 2018, $\operatorname{COM}(2018)$ 435 final, available at: https://eur-lex.europa.eu/legal-content/EN/TXT /?uri=COM\%3A2018\%3A436\%3AFIN (accessed December 25, 2019).

63. European Commission, Presentation, Horizon Europe, The Next EU Research and Innovation Investment Programme (2021-2027), May 2019/Version 25, available at: https://ec.europa.eu/info/sites/info/ files/research_and_innovation/ec_rtd_he-presentation_062019_en.pdf (accessed December 15, 2019). 
64. European Commission, The Lund Declaration, July 2009.

65. European Commission: Communication from the Commission to the European Parliament, the European Council, the European Economic and Social Committee, and the Committee of the Regions, The European Green Deal, Brussels, December 11, 2019, COM(2019) 640 final, available at: https://ec.europa.eu/info/sites/info/files/european-greendeal-communication_en.pdf (accessed December 25, 2019).

66. EU Council Meets to Debate Green Deal Grand Plan for Tackling Climate Change, Science Business, December 12, 2019, available at: https://sciencebusiness.net/news/eu-council-meets-debate-green-deal-grand-plantackling-climate-change (accessed December 25, 2019).

67. European Commission, Presentation, Horizon Europe, The Next EU Research and Innovation Investment Programme (2021-2027), May 2019/Version 25, available at: https://ec.europa.eu/info/sites/info/ files/research_and_innovation/ec_rtd_he-presentation_062019_en.pdf (accessed December 15, 2019). 